\title{
In vitro anticancer activity of Anemopsis californica
}

\author{
CATHERINE N. KAMINSKI ${ }^{1 *}$, SETH L. FERREY ${ }^{1 *}$, TIMOTHY LOWREY ${ }^{2}$, LEO GUERRA ${ }^{1}$, \\ SEVERINE VAN SLAMBROUCK ${ }^{1}$ and WIM F.A. STEELANT ${ }^{1}$
}

\author{
${ }^{1}$ Laboratory of Biochemical and Biomedical Research, Department of Chemistry, New Mexico Tech, Socorro; \\ ${ }^{2}$ UNM Herbarium, Museum of Southwestern Biology, University of New Mexico, Albuquerque, NM, USA
}

Received February 1, 2010; Accepted March 29, 2010

DOI: 10.3892/ol_00000124

\begin{abstract}
Three different extract conditions (aqueous, EtOH and EtOAc) of four different parts (bracts, leaves, roots and stems) of the plant Anemopsis californica (A. californica) were evaluated for their effect on the growth and migration of human colon cancer cells, HCT-8, and the breast cancer cell lines Hs 578T and MCF-7/AZ. Our aim was to identify potential anticancer activity in crude A. californica extracts, given that this plant is used by Native Americans to treat a variety of diseases, including cancer. Our results demonstrated that for each of the cell lines tested, the majority of ethyl acetate extracts of all the plant parts are more toxic than the aqueous and ethanol extracts. Furthermore, significant growth inhibitory activity against the three cell lines was found for the ethyl acetate extract of the roots, while the aqueous extract of the roots influenced the migratory capacity of the three cell lines. This study provides evidence for the anticancer properties of A. californica when extracted in water and ethyl acetate, and supports the importance for further purification of the crude extracts and isolation of potential new anticancer compounds through bio-guided fractionation.
\end{abstract}

\section{Introduction}

Nature is an important source of medicinal products. Subsequently, numerous useful drugs have been developed from natural sources. In particular, plants provide valuable anticancer agents with novel structures and unique mechanisms of action (1). Evidence of such successes in natural

Correspondence to: Professor Wim F.A. Steelant, Laboratory of Biochemical and Biomedical Research, Department of Chemistry, New Mexico Tech, Socorro, NM 87801, USA

E-mail: steelant@nmt.edu

*Contributed equally

Abbreviations: MTT, 3-(4,5-dimethylthiazol-2-yl)-2,5-diphenyltetrazoliumbromide; SRB, Sulforhodamine B; EDTA, ethylene diamine tetraacetic acid

Key words: Anemopsis californica, extracts, traditional medicine, cytotoxicity, growth, migration product drug discovery include the isolation of vinca-alkaloids, vinblastine and vincristine from the Madagascar periwinkle Catharanthus roseus, as well as paclitaxel from the bark of the Pacific Yew Taxus brevifolia (2). Various parts of the latter and other Taxus species are used by Native Americans for a variety of disease indications, including cancer (3). Similarly, Anemopsis californica (A. californica), a perennial plant from the Saururaceae family, native to Arizona, Southern California, Sonora and Mexico, is commonly used among Native Americans and occasionally utilized to treat illnesses with cancer-like symptoms. This knowledge was obtained from their ancestors (personal communication with a Native American medicine man whose descendants are Yaqui and Cherokee).

Nevertheless, studies on the potential anticancer activity of A. californica are rare, ambiguous (4) and largely performed with essential oils, but provide some preliminary data supporting its anticancer properties (5). Thus, this study evaluated the effects of extracts obtained from different plant parts (bracts, leaves, roots and stems) on the growth and migration of human cancer cell lines, including HCT-8 colon, mammary estrogen-independent Hs 578T and estrogen-dependent MCF-7/AZ cells. For each plant part, three extract conditions were used, including water, EtOH and EtOAc, in order to correlate to traditionally used methods and compounds with different polarities as a starting point for future bio-guided fractionation.

\section{Materials and methods}

Plant materials and preparation of extracts. Whole plants of Anemopsis californica (Saururaceae) were collected in Valencia County, located two miles south of Los Lunas, New Mexico in August 2008. The plants were identified by Dr Tim Lowrey, UNM Herbarium, Museum of Southwestern Biology, University of New Mexico, Albuquerque, NM, USA. A voucher specimen (No. 2185) was deposited at the UNM Herbarium collections for further reference and is available via the NMBCC online database (http://www.nmbiodiversity. org). The whole plants were rinsed to remove dust and/or soil and dried in a plant drier at $38^{\circ} \mathrm{C}$. The different parts were separated and cut into smaller samples. Dried plant parts $(50 \mathrm{~g}$ ) were macerated in $500 \mathrm{ml}$ solvent (water, EtOH and EtOAc) for $24 \mathrm{~h}$ under constant shaking at $4^{\circ} \mathrm{C}$. The mixtures were filtered to remove particulate matter, lyophilized and the 
Table I. Plant parts and extract conditions of A. californica and their cytotoxicity against three human cancer cell lines in vitro.

\begin{tabular}{|c|c|c|c|c|c|c|c|c|}
\hline \multirow[t]{2}{*}{ Plant part } & \multirow[t]{2}{*}{ Solvent } & \multirow[t]{2}{*}{ Yield of extraction (\%) } & \multicolumn{3}{|c|}{$\mathrm{IC}_{50}(\mu \mathrm{g} / \mathrm{ml})$} & \multicolumn{3}{|c|}{$\mathrm{IC}_{20}(\mu \mathrm{g} / \mathrm{ml})$} \\
\hline & & & НCT-8 & Hs $578 \mathrm{~T}$ & MCF-7/AZ & HCT-8 & Hs $578 \mathrm{~T}$ & MCF-7/AZ \\
\hline \multirow[t]{3}{*}{ Bracts } & $\mathrm{H}_{2} \mathrm{O}$ & 18.08 & $>200$ & $>200$ & $>200$ & 40 & $>200$ & 100 \\
\hline & $\mathrm{EtOH}$ & 9.53 & $>200$ & $>200$ & $>200$ & 60 & $>200$ & $>200$ \\
\hline & EtOAc & 1.15 & 200 & 150 & 150 & 10 & 10 & 30 \\
\hline \multirow[t]{3}{*}{ Leaves } & $\mathrm{H}_{2} \mathrm{O}$ & 14.58 & 180 & $>200$ & $>200$ & 30 & $>200$ & $>200$ \\
\hline & $\mathrm{EtOH}$ & 4.07 & $>200$ & $>200$ & $>200$ & 40 & $>200$ & 180 \\
\hline & EtOAc & 1.53 & 180 & $>200$ & 200 & 50 & 120 & 40 \\
\hline \multirow[t]{3}{*}{ Roots } & $\mathrm{H}_{2} \mathrm{O}$ & 8.83 & $>200$ & $>200$ & $>200$ & 120 & $>200$ & 40 \\
\hline & $\mathrm{EtOH}$ & 5.85 & $>200$ & 180 & 120 & 180 & 30 & 20 \\
\hline & EtOAc & 0.31 & 120 & 120 & 100 & 80 & 70 & 20 \\
\hline \multirow[t]{3}{*}{ Stems } & $\mathrm{H}_{2} \mathrm{O}$ & 10.53 & $>200$ & $>200$ & $>200$ & $>200$ & $>200$ & $>200$ \\
\hline & $\mathrm{EtOH}$ & 1.59 & $>200$ & $>200$ & $>200$ & $>200$ & $>200$ & $>200$ \\
\hline & EtOAc & 0.38 & 100 & 100 & 100 & 10 & 10 & 10 \\
\hline
\end{tabular}

Results represent means from three independent experiments, each performed in eight duplicates, determined by the MTT assay.

resulting powders were stored in a desiccator at $4^{\circ} \mathrm{C}$. Table I shows the yields obtained from the different parts and their particular solvents.

Cell culture. The HCT-8 (ATCC no. CCL-244) and Hs 578T (ATCC no. HTB-126) cell lines were obtained from the American Type Culture Collection (ATCC). MCF-7/AZ is a variant of the human mammary carcinoma cell family MCF-7 (6). The cells were maintained at $37^{\circ} \mathrm{C}$ in the appropriate media supplemented with $100 \mathrm{IU} / \mathrm{ml}$ penicillin, $100 \mu \mathrm{g} / \mathrm{ml}$ streptomycin and $10 \%$ fetal bovine serum (FBS) (Invitrogen, CA, USA), in a humidified atmosphere containing 5 or $10 \%$ $\mathrm{CO}_{2}$.

In vitro cytotoxicity assay. The effect of the extracts on cell viability was tested in accordance with Romijn et al (7). Briefly, mitochondrial dehydrogenase activities were measured by an MTT reagent (Sigma, MO, USA). Cells were seeded in 96-well plates at an initial density of $1.5 \times 10^{4}$ cells in $200 \mu \mathrm{l}$ of the appropriate culture medium. After a 24-h incubation, cells were treated with 10 concentrations $(20,40,60,80,100,120,140,160,180$ and $200 \mu \mathrm{g} / \mathrm{ml})$ of the different crude extracts in culture medium. After a 24and 72-h incubation, $100 \mu \mathrm{l}$ medium was removed prior to the addition of MTT. To determine the mean optical density (OD) referring to cell viability in the three independent experiments, eight wells were used for each condition and concentration. $\mathrm{IC}_{50}$ and $\mathrm{IC}_{20}$ values were determined from the graphs and are expressed as a percentage compared to solvent-treated controls.

\section{In vitro cell growth assay}

Sulforhodamine B assay (SRB). Cells were seeded in 96-well plates at an initial density of $1.5 \times 10^{4}$ cells in $200 \mu \mathrm{l}$ of the appropriate culture medium. After a 24-h incubation, cells were treated with increasing concentrations $(20,40,60,80$,
$100,120,140,160,180$ and $200 \mu \mathrm{g} / \mathrm{ml}$ ) of each crude extract. Concentrations were adjusted to the results obtained after the MTT assays, and lower concentrations and smaller increments $(1,5,10,15,20,25,30,40,45,50$ or $10,20,30,40,50,60,70$, $80,90,100 \mu \mathrm{g} / \mathrm{ml}$ ) were used for most of the toxic extracts. Following a 72-h incubation, the amount of cell protein in each well was estimated with the Sulforhodamine B assay (Sigma) as described previously (8). In three independent experiments, eight wells were used for each condition and concentration, to determine the mean OD referring to cell growth. The percentage of growth inhibition at the $\mathrm{IC}_{20}$ values was determined from the graphs and compared to solventtreated controls.

Cell counting assay. Cells were seeded in $25-\mathrm{cm}^{2}$ culture flasks at a density of $1.5 \times 10^{5}$ cells in $5 \mathrm{ml}$ of the appropriate culture medium. The cells were grown in the presence or absence of the crude extracts in concentrations, determined in the 72-h MTT assays, harvested using trypsin/EDTA and counted with a hemacytometer (Hausser Scientific, Horsham, PA, USA). At least three independent experiments were performed to determine the mean value, which is presented as a percentage as compared to the solvent-treated controls.

In vitro wound-healing assay. Cells were grown in 6-well plates until confluency in the appropriate medium and then washed twice with PBS. After wounding the cells, $3 \mathrm{ml}$ of medium in the presence or absence of the crude extracts, at a concentration previously determined in the 24-h MTT assays, was added. After $24 \mathrm{~h}$, the distances over which the cells migrated were measured and expressed as migratory velocity $(\mu \mathrm{m} / \mathrm{h})$. At least three independent experiments were performed (9).

Statistics. Treatments were matched and performed at least three times. Data were analyzed as means $\pm \mathrm{SD}$, using Student's t-test (95\%). 


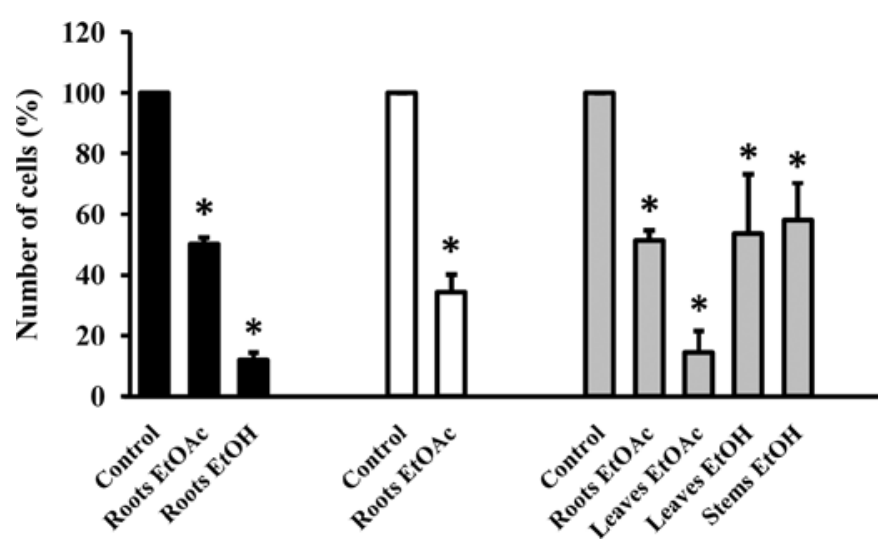

Figure 1. Growth inhibitory effect of selected crude extracts of A. californica against colon HCT-8 (black bars), Hs 578T (white bars) and MCF-7/AZ breast (grey bars) cancer cells, treated with the respective $\mathrm{IC}_{20}$ concentrations for $72 \mathrm{~h}$. The number of cells was determined by counting and expressed as a percentage of solvent-treated control cells. "Statistical difference from solvent-treated control cells $(\mathrm{p}<0.05)$.

\section{Results}

Extracts of Anemopsis californica and cell viability. The MTT test was used to determine the cytotoxicity of each extract on the cell lines studied. The $\mathrm{IC}_{50}$ values, as compared to solvent-treated control conditions, are shown in Table I (left panel). Additionally, concentrations at which $80 \%$ of the cells remain viable $\left(\mathrm{IC}_{20}\right)$ were determined, after $24 \mathrm{~h}$ (Table $\mathrm{I}$, right panel) and $72 \mathrm{~h}$ (data not shown), and used in subsequent experiments to eliminate confounding effects due to cytotoxicity. The EtOAc extracts of the plant parts (bracts, leaves, roots and stems) appear to be more toxic than the aqueous and $\mathrm{EtOH}$ extracts in the cell lines tested. Additionally, the aqueous and ethanol extracts of the stems at concentrations up to $200 \mu \mathrm{g} / \mathrm{ml}$ did not affect the cell viability of these cell lines. On the other hand, the EtOH and aqueous extracts of the bracts, leaves and roots exerted variable effects.

EtOH and EtOAc extracts reduce cell growth. Subsequently, the extracts were evaluated for growth inhibitory activity against the cell lines studied. The EtOAc extracts of the roots markedly inhibited the growth of the cell lines by $\geq 50 \%$, as determined by SRB and confirmed by cell count after $72 \mathrm{~h}$ (Fig. 1, Table II, numbers in bold). EtOAc and EtOH extracts of the leaves and the EtOH extract of the stems showed growth inhibitory activity on MCF-7/AZ cells, while the growth of HCT-8 colon cancer cells was significantly influenced by the EtOH extract of the roots. The majority of extracts did not affect the growth of the Hs 578T breast cancer cells and no activity was found for each of the aqueous extracts (Table II).

Aqueous extract of the roots inhibits migration. Since the migration of cancer cells is affected by their growth, we used the extracts that did not significantly influence cell growth and tested them on the migratory capacity of the cell lines. As shown in Fig. 2 (upper panel), the majority of the extracts did not influence the migratory capacity of the colon cancer cell line, except for the aqueous extract of the roots. An even more pronounced effect (by $>80 \%$ ) was observed in the MCF-7/
Table II. Growth inhibitory effect of crude extracts of A. californica against three human cancer cell lines in vitro.

\begin{tabular}{lcccr}
\hline \multirow{2}{*}{ Plant part } & Solvent & \multicolumn{3}{c}{ Growth (\%) } \\
\cline { 3 - 5 } & & $\mathrm{HCT}-8$ & $\mathrm{Hs} 578 \mathrm{~T}$ & $\mathrm{MCF}-7 / \mathrm{AZ}$ \\
\hline \multirow{2}{*}{ Bracts } & $\mathrm{H}_{2} \mathrm{O}$ & $95 \pm 3$ & $100 \pm 4$ & $107 \pm 5$ \\
& $\mathrm{EtOH}$ & $105 \pm 7$ & $85 \pm 6$ & $80 \pm 6$ \\
& $\mathrm{EtOAc}$ & $100 \pm 2$ & $71 \pm 5$ & $86 \pm 4$ \\
Leaves & $\mathrm{H}_{2} \mathrm{O}$ & $102 \pm 3$ & $94 \pm 4$ & $103 \pm 3$ \\
& $\mathrm{EtOH}$ & $102 \pm 2$ & $78 \pm 10$ & $\mathbf{6 3} \pm \mathbf{2}$ \\
& $\mathrm{EtOAc}$ & $92 \pm 5$ & $78 \pm 8$ & $\mathbf{4 4} \pm \mathbf{1}$ \\
Roots & $\mathrm{H}_{2} \mathrm{O}$ & $96 \pm 4$ & $100 \pm 8$ & $105 \pm 2$ \\
& $\mathrm{EtOH}$ & $\mathbf{1 4} \pm \mathbf{5}$ & $85 \pm 2$ & $91 \pm 6$ \\
& $\mathrm{EtOAc}$ & $\mathbf{4 6} \pm \mathbf{4}$ & $\mathbf{2 7} \pm \mathbf{2}$ & $\mathbf{4 7} \pm \mathbf{2}$ \\
Stems & $\mathrm{H}_{2} \mathrm{O}$ & $110 \pm 1$ & $89 \pm 10$ & $102 \pm 4$ \\
& $\mathrm{EtOH}$ & $71 \pm 9$ & $104 \pm 5$ & $\mathbf{5 7 \pm 3}$ \\
& EtOAc & $85 \pm 4$ & $74 \pm 4$ & $90 \pm 4$ \\
\hline
\end{tabular}

Percentage of cell growth after 72-h treatment with indicated extracts relative to solvent-treated controls \pm SD from three independent experiments, each performed in eight duplicates, determined by SRB assay.

AZ and Hs 578T cell lines (Fig. 2, lower panel). Furthermore, several extracts were able to inhibit the migration of MCF-7/ AZ and Hs 578T breast cancer cells.

\section{Discussion}

Results of the present study showed that crude extracts of the plant A. californica, obtained through methods that correlate with its traditional use by Native Americans, contain potent anticancer agents. While most of the activity was found for extracts of the roots, results of other plant parts and their particular extraction method could be ignored. For example, the EtOAc and EtOH extracts of the leaves and the EtOH extract of the stems inhibited the growth of MCF-7/AZ but not Hs 578T breast cancer cells. This difference suggests that these crude extracts contain compounds that have an impact on the estrogen-dependency of MCF-7/AZ cells. No growth inhibitory activity was found for the aqueous extracts, indicating that potential compounds for this activity are of a less polar nature. In a preliminary study conducted on A. californica roots, cytotoxicity values were within the same range. However, a discrepancy in the growth effect was noted (6). This can be explained by the fact that the roots of $A$. californica were previously obtained from a local herb store and little was known on how they were harvested and processed; thus, there was no guarantee that the specimens were unadulterated. This emphasizes the importance that WHO guidelines should be followed at all times ensuring proper harvest and quality assurance of medicinal plants (10).

Migratory and invasive capacities are important characteristics that distinguish benign from malignant lesions. It is now increasingly accepted that the migration and invasion process offers a rich source of novel targets for therapy and that inhibi- 

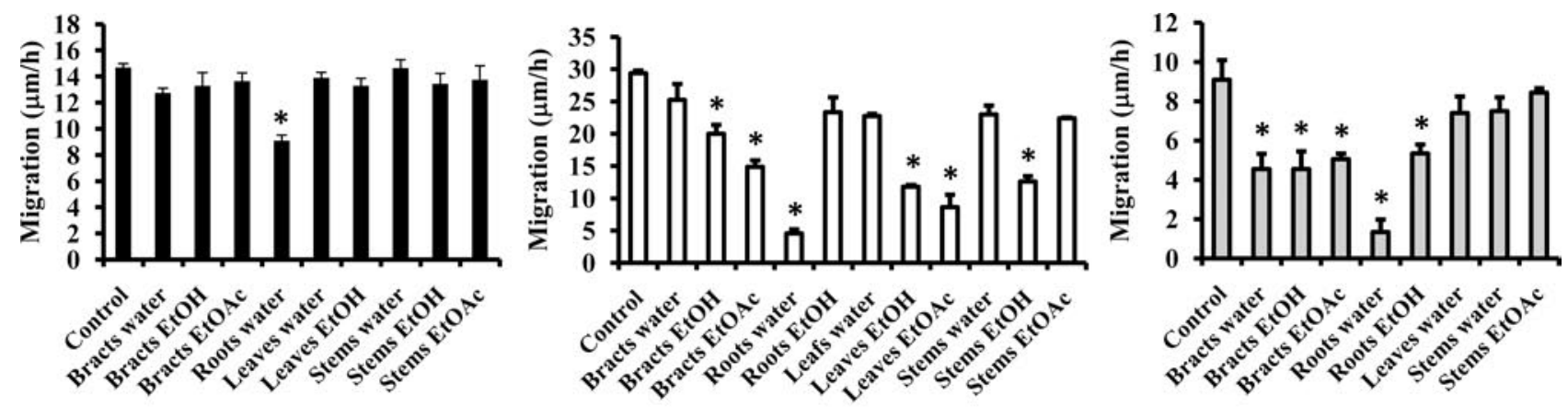

A

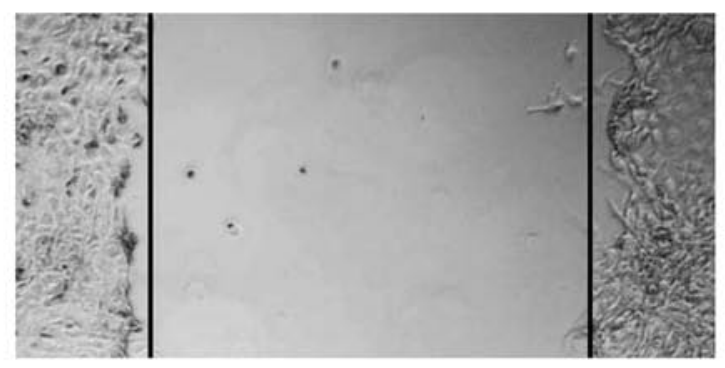

C

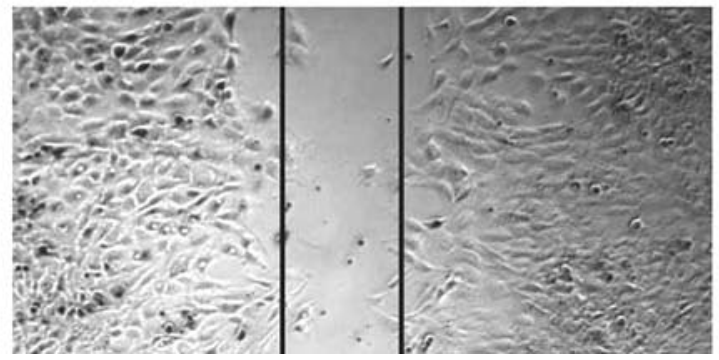

B

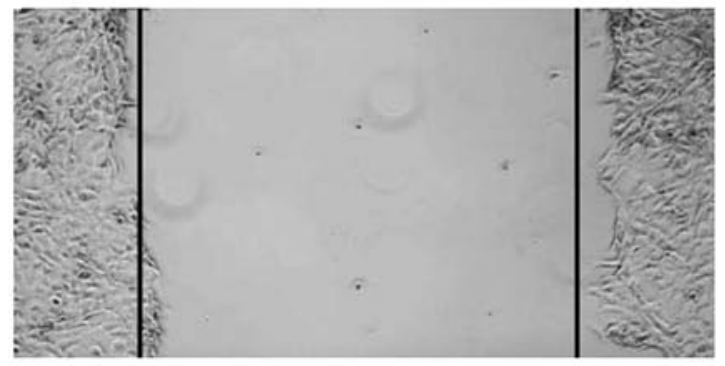

D

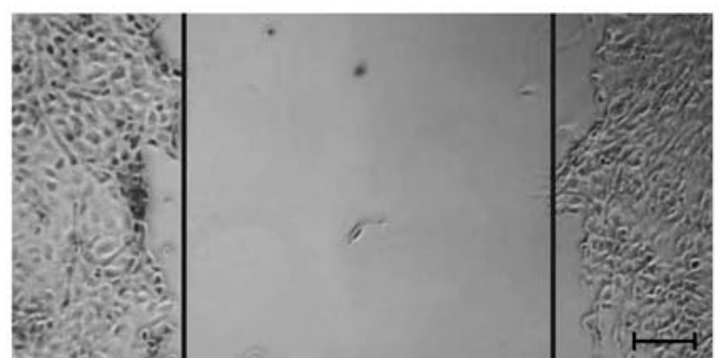

Figure 2. Effect of selected crude extracts of A. californica on cell migration. The top panel shows colon HCT-8 (black bars), Hs 578T (white bars) and MCF-7/AZ breast (grey bars) cancer cells, treated with the respective $\mathrm{IC}_{20}$ concentrations. After $24 \mathrm{~h}$, the distances of cell migration were measured and results are expressed as migratory velocity $(\mu \mathrm{m} / \mathrm{h}) .{ }^{*}$ Statistical difference from solvent-treated control cells $(\mathrm{p}<0.05)$. $(\mathrm{A}-\mathrm{D})$ : Wounded Hs $578 \mathrm{~T}$ cells $(0 \mathrm{~h})(\mathrm{A}$ and B), and treated (24 h) (D) or not (C) with water extract of roots are shown. Scale bar, $30 \mu \mathrm{m}$.

tors control tumor metastasis (11). Therefore, we determined the influence of the extracts that did not affect cell growth on the migratory capacity of the cell lines. We observed that a number of extracts reduced the migratory capacity to a certain extent, mainly in MCF-7/AZ and Hs 578T cells. Of particular interest is the aqueous extract of the roots, which is able to inhibit migration of all three cell lines and for MCF-7/ AZ and Hs $578 \mathrm{~T}$ by more than $80 \%$. This effect occurred at non-toxic concentrations, but did not affect cell growth. The latter result suggests that the more polar compounds are predominantly responsible for the reduced migratory velocity. Only limited information on the composition of the compound is available in the literature, mainly on essential oils of leaves and roots. Herein, methyleugenol and elemicin were identified as major constituents, next to thymol and piperitone (12-15). A recent study relates these compounds to the growth inhibition of AN3CA and HeLa cells (5). However, no reports are currently available to support the anti-migratory effect. This suggests that other constituents are present in A. californica, which explains the activity of the crude aqueous root extract. A literature search of medicinal plant extracts affecting the migration and invasion of cancer cells revealed that flavonoids, alkaloids and phenylpropanoids are possible candidate compound classes $(16,17)$. In this regard, the flavonoid evodiamine, one of the main constituents of Evodiae Fructus, was found to inhibit tumor cell migration with low cytotoxicity and an insignificant effect on cell growth (17). Further purification of the crude extracts and isolation of the active constituents is necessary to correlate our findings to these classes of molecules.

In conclusion, our investigation showed that aqueous and EtOAc extracts of A. californica roots possess pronounced anticancer activity against multiple human cancer cell lines, an effect that could be observed independently of the presence of the estrogen receptor. These extracts are currently under consideration in our laboratory for bio-guided fractionation. Additionally, the extracts of the leaves and stems, showing specificity against the hormone-dependent MCF-7/AZ cells, warrant further evaluation against known compounds affecting estrogen receptor responsiveness.

\section{Acknowledgements}

This work was supported by the US National Institutes of Health (1R15 AT002888-01A2), the NSF (0755469) CHE-MPS/CHE-Undergraduate Programs in Chemistry, and the New Mexico Tech startup funds. The authors are grateful to Margaret Garcia for the plant identification. 


\section{References}

1. Cragg GM, Grothaus PG and Newman DJ: Impact of natural products on developing new anti-cancer agents. Chem Rev 109: 3012-3043, 2009.

2. Cragg GM and Newman DJ: Plants as a source of anti-cancer agents. J Ethnopharmacol 100: 72-77, 2005.

3. Moerman DE: Native American Ethnobotany. 5th edition. Timber Press, pp11-13, 1998.

4. Childs RF and Cole JR: Phytochemical and pharmacological investigation of Anemopsis californica. J Pharm Sciences 54: 789-791, 1965.

5. Medina-Holguin AL, Holguin FO, Micheletto S, Goehle S, Simon JA and O'Connel MA: Chemotypic variation of essential oils in the medicinal plant, Anemopsis californica. Phytochemistry 69: 919-927, 2008.

6. Daniels AL, van Slambrouck S, Lee RK, Arguello TS, Browning J, Pullin MJ, Kornienko A and Steelant WF: Effects of extracts from two Native American plants on proliferation of human breast and colon cancer cell lines in vitro. Oncol Rep 15: 1327-1331, 2006.

7. Romijn JC, Verkoelen CF and Schroeder FH: Application of the MTT-assay to human prostate cancer cell lines in vitro: establishment of test conditions and assessment of hormonestimulated growth and drug-induced cytostatic and cytotoxic effects. Prostate 12: 99-110, 1988.

8. Skehan P, Stroeng R, Scudiero D, Monks A, McMahon J, Vistica D, Warren JT, Bokesch H, Kenney S and Boyd MR: New colorimetric cytotoxicity assay for anticancer drug screening. J Natl Cancer Inst 82: 1107-1112, 1990.
9. Van Slambrouck S, Hilkens J, Bisoffi $M$ and Steelant WFA: AsialoGM1 and integrin $\alpha 2 \beta 1$ mediate prostate cancer progression. Int J Oncol 35: 693-699, 2009.

10. WHO guidelines on good agricultural and collection practices (GAPC) for medicinal plants. World Health Organization, Geneva, 2003.

11. Mareel $\mathrm{M}$ and Leroy A: Clinical, cellular and molecular aspects of cancer invasion. Physiol Rev 83: 337-376, 2003.

12. Horton WJ and Paul EG: 4-Allylveratrole from Anemopsis californica. J Am Chem Soc 79: 2264-2266, 1957.

13. Acharya RN and Chaubal MG: Essential oil of Anemopsis californica. J Pharm Sciences 57: 1020-1022, 1968.

14. Sanvordeker DR and Chaubal MG: Essential oil of Anemopsis californica Part II: minor constituents. J Pharm Sciences 58: 1213-1217, 1969.

15. Tutupalli LV and Chaubal MG: Composition of essential oil from foliage of Houttuynia cordate and chemosystematics of Saururaceae. Lloydia 38: 92-96, 1975.

16. Ogasawara M, Matsubara $\mathrm{T}$ and Suzuki H: Screening of natural compounds for inhibitory activity on colon cancer cell migration. Biol Pharm Bull 24: 720-723, 2001.

17. Lee SJ, Lee KW, Hur HJ, Chun JY, Kim SY and Lee HJ: Phenolic phytochemicals derived from red pine (Pinus densiflora) inhibit the invasion and migration of SK-Hep-1 human hepatocellular carcinoma cells. Ann NY Acad Sci 1095: 536-544, 2007. 